\title{
Activity of A-56268 (TE-031), a new macrolide, against Toxoplasma gondii in mice
}

\author{
Hernan R. Chang*, Florin C. Rudareanu and Jean-Claude Pechère \\ Department of Microbiology, University of Geneva Medical School. \\ C.M.U., 9 av. de Champel, 1211 Geneva 4, Switzerland
}

\begin{abstract}
The activity of A-56268 (TE-031), a new macrolide, was tested in a murine model of acute toxoplasmosis. All control animals died in $8 \pm 1$ days, while all mice treated with nine daily doses of A-56268 at $300 \mathrm{mg} / \mathrm{kg}$, administered by gavage, survived. Moreover, $41.6 \%$ of the surviving mice were free from cerebral infection with Toxoplasma gondii, as assessed by brain subpassage. A-56268 is active against $T$. gondii in vivo, but further studies are needed to determine its usefulness in the treatment of human toxoplasmosis.
\end{abstract}

\section{Introduction}

Toxoplasma gondii is one of the leading causes of encephalitis in the patients with AIDS. The current treatment of choice is the synergistic combination of pyrimethamine and a sulphonamide. Unfortunately, the high rate of side effects observed with this combination in AIDS patients makes it necessary to discontinue the therapy in many cases. Because the treatment is only active against the replicating tachyzoite and not against the tissue cyst form of the parasite, relapse has been observed upon withdrawal of chemotherapy in most cases. Therefore there is a critical need for newer and safer compounds for the treatment of toxoplasmosis.

Several macrolides have shown some anti-toxoplasma activity. Spiramycin is recognized to reduce the risk of congenital infection in the babies of women with acute toxoplasmosis (Daffos et al., 1988). Roxithromycin, azithromycin (CP-62,993) and A-56268, which are newer macrolides, have also shown activity against $T$. gondii in vitro (Chang \& Pechère, 1988). The first two compounds have shown activity against $T$. gondii in murine models also (Araujo, Guptill \& Remington, 1987; Chang \& Pechère, 1987).

A-56268, a new 6-O-methyl derivative of erythromycin, has a similar antibacterial spectrum to erythromycin, but a longes serum half-life (Fernandes et al., 1986). Recently, we have shown that this new macrolide was able to block the incorporation of $\left[{ }^{3} \mathrm{H}\right]$ uracil by the virulent $\mathrm{RH}$ strain of $T$. gondii in murine peritoneal macrophages, the $50 \%$ inhibitory concentration being calculated at $147 \mu \mathrm{M}$ (Chang \& Pechère, 1988). Here, we have assessed the activity of A-5268 in mice heavily infected with $T$. gondii.

- Corresponding author. 


\section{Materials and methods}

A-56268, provided by Abbott Laboratories, North Chicago, Illinois, USA, in powder form, was dissolved in a small amount of ethanol and suspended in $0.25 \%$ carboxy methylcellulose in sterile water. Female Swiss-Webster mice were infected intraperitoneally with 5000 tachyzoites of the virulent RH strain of $T$. gondii as previously described (Chang \& Pechère, 1987). Animals were randomly allocated to groups of six and kept in conventional cages with free access to food and water. The study period lasted 30 days with treatment starting $24 \mathrm{~h}$ after challenge and continuing for nine days. The drug was delivered in $0.5 \mathrm{ml}$ of suspension by gavage once a day with a feeding needle. At the end of the study period the surviving mice were killed and autopsied. Peritoneal fluids were examined microscopically $(x 400)$ for the presence of tachyzoites. When no parasites were seen, the brain was ground with fine glass beads in a mortar containing $5 \mathrm{ml}$ sterile $0.9 \% \mathrm{NaCl}$. A portion $(1 \mathrm{ml})$ of this suspension was injected into each of two new untreated mice to determine whether the treatment resulted in eradication of $T$. gondii from the brain. The donor was considered cured if the two recipient mice survived 30 days after injection without having toxoplasma infection at autopsy.

\section{Results}

The results are shown in Table I. A dose of $300 \mathrm{mg} / \mathrm{kg} /$ day of A-56268 given for nine days protected $100 \%$ of the mice ( $P<0.001$, compared with untreated controls). Also, a single dose of $600 \mathrm{mg} / \mathrm{kg}$, started sixh after challenge, protected $25 \%$ of the mice.

Table I. Therapeutic effects obtained with A-56268

\begin{tabular}{|c|c|c|c|c|}
\hline Treatment & $\begin{array}{c}\text { Dose } \\
(\mathrm{mg} / \mathrm{kg})\end{array}$ & $\begin{array}{l}\text { Time to death } \\
\text { for } 50 \% \text { of } \\
\text { mice (days) }\end{array}$ & $\begin{array}{l}\text { No. of } \\
\text { survivors/ } \\
\text { no. of mice } \\
(\%)\end{array}$ & $\begin{array}{c}\text { No. of } \\
\text { survivors } \\
\text { cured (\%) }\end{array}$ \\
\hline \multirow[t]{3}{*}{ A-56268 } & $\begin{array}{c}150 \mathrm{mg} / \mathrm{kg} / \text { day; } \\
9 \text { days }\end{array}$ & 15 & $3 / 6 \quad(50)$ & $2(66 \cdot 6)$ \\
\hline & $\begin{array}{c}200 \mathrm{mg} / \mathbf{k g} / \text { day; } \\
9 \text { days }\end{array}$ & 一 & $5 / 6 \quad(83.4)$ & $2(40)$ \\
\hline & $\begin{array}{c}300 \mathrm{mg} / \mathrm{kg} / \mathrm{day} \\
9 \mathrm{days}^{b}\end{array}$ & no deaths & $6 / 6 \quad(100)$ & $1(16 \cdot 6)$ \\
\hline A-56268 & $\begin{array}{l}600 \mathrm{mg} / \mathrm{kg} \\
\text { single dose }\end{array}$ & 11 & $2 / 8$ & $2(100)$ \\
\hline Controls & & $8 \pm 1^{d}$ & $0 / 12(0)$ & \\
\hline
\end{tabular}

Whthout residual cerebral infection; "commenang $24 \mathrm{~h}$ after challenge; ' $6 \mathrm{~h}$ after challenge; ${ }^{4}$ time to death for all mice.

The cure rates obtained after brain transfer are also presented in Table $\mathrm{I}$. The overall cure rate obtained was $41 \cdot 6 \%$. The cure rate obtained with the single dose of A-56268 in the two survivors was $100 \%$.

\section{Discussion}

A-56268 was effective in treating acute murine toxoplasmosis, as $2.7 \mathrm{~g} / \mathrm{kg}$ of the drug given in nine days protected all the animals from a lethal infection. This compares with 
roxithromycin, where, in the same animal model, but in a 5-dose (rather than a 9-dose) treatment the same amount of $2.7 \mathrm{~g} / \mathrm{kg}$ produced the same protective effect (Chang \& Pechère, 1987). Both compounds performed better than spiramycin in the sense that the $100 \%$ survival dose of spiramycin cannot be determined for toxicity reasons (Chang \& Pechère, 1987).

During the natural course of our experimental infection, dissemination of $T$. gondii throughout the body follows the intraperitoneal challenge. All untreated mice have a brain infection before death (Chang \& Pechère, 1987), but the exact timing of the cerebral infection is unknown. Therefore, the cure rate calculated here may reflect either a preventive or therapeutic effect. At least in the case of the single A-56268 therapy, where the drug was administered $6 \mathrm{~h}$ after peritoneal challenge, i.e. a relatively short time interval, the $100 \%$ cure rate in the surviving mice might well be due to a preventive rather than a truly curative effect. This observation suggests that against $T$. gondii, A-56268 has essentially an inhibitory rather than a cidal effect, as previously shown in vitro (Chang \& Pechère, 1988).

These results demonstrate that A-56268 is active against acute murine toxoplasmosis and confirm our previous in-vitro findings. Further clinical studies are warranted to determine whether or not this compound would be useful in the treatment of toxoplasma infections, in man.

\section{Acknowledgements}

We thank Hilles Hamersley for her excellent secretarial assistance. This work was supported in part by grant 3.221-085 from the Fonds National Suisse de la recherche Scientifique.

\section{References}

Araujo, F. G., Guptill, D. R. \& Remington, J. S. (1987). CP-62, 993, a new macrolide antibiotic with potent activity against Toxoplasma gondii. In Program and Abstracts of the TwentySeventh Interscience Conference on Antimicrabial Agents and Chemotherapy. New York, 1987. Abstract 234. p. 136. American Society for Microbiology, Washington, DC.

Chang, H. R. \& Pechère, J.-C.F. (1987). Effect of roxithromycin on acute toxoplasmosis in mice. Antimicrobial Agents and Chemotherapy 31, 1147-9.

Chang, H. R. \& Pechère, J.-C.F. (1988). In vitro effect of four macrolides (roxithromycin, spiramycin, azithromycin [CP-62, 993], and A-56268) on Toxoplasma gondii. Antimicrobial Agents and Chemotherapy 32, 524-9.

Daffos, F., Forestier, F., Capella-Pavlovsky, M., Thulliez, P., Aufrant, C., Valenti, D. et al. (1988). Prenatal management of 746 pregnancies at risk for congenital toxoplasmosis. New England Journal of Medicine 318, 271-5.

Fernandes, P. B., Bailer, R., Swanson, R., Hanson, C. H. McDonald, E., Ramer, N. et al. (1986). In vitro and in vivo evaluation of A-56268 (TE-031), a new macrolide. Antimicrobial Agents and Chemotherapy 30, 865-73. 